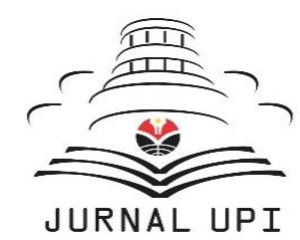

INDONESIAN JOURNAL OF APPLIED LINGUISTICS

Vol. 10 No. 3, January 2021, pp. 771-781

Available online at:

https://ejournal.upi.edu/index.php/IJAL/article/view/31765

https://doi.org/10.17509/ijal.v10i3.31765

\title{
Exploring EFL university learners' acquisition of advanced reading skills in the Yemeni context
}

\author{
Waleed Mohammed A. Ahmed \\ English Department, Faculty of Human and Social Sciences, University of Science and Technology, \\ P.O. Box: 13064, Sana'a, Yemen
}

\begin{abstract}
Reading is an essential language skill for enhancing learners' performance at various levels of study. However, EFL learners at the tertiary level encounter reading difficulties, particularly in acquiring advanced reading skills, which have affected their reading comprehension and resulted in low academic performance achievement. This is probably attributed to various factors, including learners' lack of effective reading strategies. A study that exclusively explores reading difficulties encountered by EFL university learners, reasons for the difficulties, and strategies adopted to overcome the difficulties and develop advanced reading skills seem to be scarce in the literature. Therefore, the main purpose of this study was to explore the acquisition process of advanced reading skills in EFL tertiary context at a private university in Yemen from learners' perspective. The study adopted a qualitative approach to gather data from EFL tertiary learners through a focus group discussion. The data were analyzed manually using the indexing approach. Findings revealed that learners face reading difficulties such as inference making, getting the gist of the text, and managing the reading tasks. These difficulties were attributed to linguistic and non-linguistic reasons, and metacognitive, cognitive, and social-affective strategies were used in reading. The study recommends engaging EFL learners in intensive and extensive reading to help them apply the strategies they learn and develop advanced reading skills and better academic performance. Future research studies may focus on strategies for reading fluency.
\end{abstract}

Keywords: Advanced reading; EFL tertiary context; reading difficulties; reading strategies

\begin{tabular}{|c|c|c|}
\hline $\begin{array}{l}\text { First Received: } \\
22 \text { August } 2020 \\
\text { Final Proof Received: } \\
\text { 17 January } 2021\end{array}$ & $\begin{array}{c}\text { Revised: } \\
4 \text { November } 2020\end{array}$ & $\begin{array}{l}\text { Accepted: } \\
\text { 12 December } 2020 \\
\text { Published: } \\
\text { 31 January 2021 }\end{array}$ \\
\hline \multicolumn{3}{|c|}{$\begin{array}{l}\text { How to cite (in APA style): } \\
\text { Ahmed, W. M. A. (2021). Exploring EFL learners' acquisition of advanced reading skills in } \\
\text { university Yemeni context. Indonesian Journal of Applied Linguistics, 10(3), 771-781. } \\
\text { https://doi.org/10.17509/ijal.v10i3.31765 }\end{array}$} \\
\hline
\end{tabular}

\section{INTRODUCTION}

Reading is an essential receptive language skill required for academic achievement. It is perceived as a vital critical thinking process for learners' success at tertiary level (Veeravagu et al., 2010). In such a process, learners at the university level need to develop advanced reading comprehension skills (Hermida, 2009; Liu \& Brown, 2019; Veeravagu et al., 2010; Zhussupova \& Kazbekova, 2016) to cope with academic tasks (Liu \& Brown, 2019). This can be achieved by engaging learners in more reading experience (Clinton, 2019; Perfetti et al., 2005) through advanced reading strategies (Perfetti et al., 2005) which are crucial for getting the deepest meaning of reading texts (Suraprajit, 2019).

Scholars have provided various definitions of reading. For instance, Kasim and Raisha (2017) viewed reading as a 'thinking process' that leads to inferring meaning from the text. Reading can also be defined as the interaction between the reader, reading text and environment in a sociocultural context (Trehearne \& Doctorow, 2005). It is a 
cognitive process in which the reader interacts with the text and author's ideas to construct meaning in relation to his previous knowledge (Veeravagu et al., 2010). Based on these definitions, reading can be perceived as a process of a complex interaction between the reader and the text in which prior knowledge and reading strategies are used to infer and construct meaning.

The interaction between the reader and the text needs to be effective for constructing meaning (Qrqez \& Ab Rashid, 2017; Yukselir, 2014). However, in the academic context, the interaction between university students as readers and the ideas in the text may not be effective. This is probably due to the fact that some university students may lack academic reading skills required for university-level reading which is different from high school reading (Hermida, 2009). This shift from school context to the university context might have created certain reading difficulties for learners. These difficulties are perceived as lower abilities in reading than expected in equivalent peers in the same learning context (Lyon et al., 2003). Such difficulties which might root in school and continue during college education (Wulfemeyer, 2019) have led to the unsatisfactory academic achievement of learners (Tarchi, 2015).

In EFL context, reading difficulties vary based on reader's experience. Struggling readers face reading difficulties in understanding new vocabulary, finding out specific information and identifying the topic of text (Fitriani, 2014), which are related to basic (low-order cognitive) skills (Allen \& Zygouris-Coe, 2019). On the other hand, advanced readers may encounter difficulties related to high-order cognitive skills (Tarchi, 2015) which include difficulty in understanding the socio-cultural aspects of the target language, linking the ideas of the text, and distinguishing between main points and supporting points (Kasim \& Raisha, 2017), and difficulty in analyzing, inferring, and evaluating information in the text (Kendeou et al., 2014).

The aforementioned difficulties may be due to the fact that university students employ a surface approach to reading in the context where they need to adopt a deep approach which focuses on the analysis, synthesis and evaluation of the text (Hermida, 2009). The former approach focuses on low-order cognitive skills while the latter is concerned with high-order cognitive skills.

Reading difficulties can be attributed to linguistic and/ or non-linguistic reasons. Linguistic reasons include lack of lexical, semantic and syntactical knowledge; and non-linguistic reasons involve lack of knowledge about effective reading strategies, lack of social-cultural knowledge of the target language text, lack of prior knowledge about the text, and lengthy texts (Kasim \& Raisha, 2017). Some other reasons for reading difficulties include lack of reading strategies (Kasim \& Raisha, 2017), nature and type of text, reader's experience, and context (Afflerbach et al., 2008).

Reading strategies are viewed as one of the vital tools that can help readers deal with reading difficulties (Afflerbach et al., 2008; Samad et al., 2017), enhance their reading skills (Afflerbach et al., 2008; Poole, 2010; Suraprajit, 2019) and, as a result, lead to the achievement of the main purpose of reading (Kenner \& Weinerman, 2011; Rasinski, 2019).

Afflerbach et al. (2008) made a clear distinction between reading strategies and reading skills. The authors viewed reading strategies as "deliberate goal-directed attempts to control and modify the reader's efforts to decode text, understand words and construct meanings of text time" while they perceived reading skills as "automatic actions that result in decoding and comprehension with speed, efficiency and fluency, and usually occur without awareness of the components or controlled involved" (Afflerbach et al., 2008, p. 368).

Reading strategies have various classifications in literature. They can be top-down and bottom-up (Goodman, 1970); metacognitive, cognitive and support strategies (Sheorey \& Mokhtari, 2001); or global, problem-solving and support (Poole, 2010). The classification adopted in this study involves the use of metacognitive, cognitive and social-affective developed by Chamot and Kupper (1989) which seem to match Sheorey and Mokhtari's (2001) strategies. These strategies may include micro strategies such as silent and fast reading (Ari, 2017), inference making (Kendeou et al., 2014), focusing on the pattern of the text (Namjoo \& Marzban, 2014), reading with peers (Tarchi, 2015), and searching for information in various resources, synthesizing information and evaluating it (Grabe, 1991).

Metacognitive reading strategies, which involve planning, monitoring and evaluation (Iwai, 2011) can help learners develop critical thinking skills (Namjoo \& Marzban, 2014) and enhance their reading performance (Ahmadi et al., 2013). Metacognitive strategies also help to monitor cognitive processes, and improve cognitive and social-affective strategies, in addition to the achievement of reading tasks' goals (Iwai, 2011).

Cognitive strategies focus on interacting with the text through analyzing, reasoning, and summarizing to create meaningful structure of the text (Sahrul, 2014). In reading, cognitive skills are stimulated through the engagement of learners in a direct interaction with reading texts where cognitive strategies, such as guessing meaning from context, inferring unstated information and ideas, are used (Wahyono, 2019). Using these strategies can help learners develop cognitive skills which are vital for enhancing academic reading skills (Liu \& Brown, 2019). 
Social-affective strategies are practised through cooperative learning. These strategies are effective for developing learners' reading skills as they facilitate sharing prior knowledge related to the text (Tarchi, 2015), help learners deal with learning difficulties, achieve the reading purposes (Liu \& Brown, 2019), and enhance their performance (Havens \& Williams, 2019; Warrican et al., 2019).

Several recent studies have been conducted to investigate reading comprehension in relation to various variables. For example, Kasim and Raisha (2017), and Qrqez and Ab Rashid (2017) investigated reading comprehension difficulties among EFL learners at the university context. Major findings indicated that learners encountered difficulties in comprehending new vocabulary. Al Seyabi and Tuzlukova (2015) investigated reading difficulties among EFL school and university learners, and strategies used to deal with the difficulties. Findings revealed that comprehending new vocabulary was the main difficulty encountered by learners. Manihuruk's (2020) investigation of correlation between learners' knowledge of vocabulary and reading comprehension showed a moderate positive correlation between knowledge of vocabulary and reading comprehension performance. However, unfamiliar vocabulary can be inferred from the context, particularly in advanced reading where the focus of reading is on high-order cognitive skills such as inference making and critical evaluation (Kendeou et al., 2014).

In the Arab EFL tertiary context, some studies have investigated learners' reading problems, strategies and comprehension skills. For instance, Raihan and Nezami (2012) investigated reading problems faced by Arab EFL university learners in Saudi Arabia. Findings revealed that learners faced difficulty in constructing meaning of the text due to lack of vocabulary. In the Yemeni EFL university context, Al-Sobhani (2013) investigated reading strategies used by undergraduate learners and found that learners used problem-solving strategies more than global and support strategies. Al Seyabi and Tuzlukova (2015) investigated reading problems encountered by Omani EFL students at post-basic and foundation university programmes and the strategies used to deal with the problems. Findings showed that, in both programmes, students faced problems related to vocabulary. Findings also revealed that students at foundation programme used higher strategies than school students. Ibrahim and Ahmed (2020) investigated teachers' perceptions of how EFL university learners in the Sudanese context can improve reading comprehension skills and found that learners' knowledge of vocabulary can help to improve reading skills. The study also revealed that EFL learners faced reading difficulties such as inferring meanings of words from context, finding explicit and implicit information in the text, linking ideas of the text and identifying the structure of the text. Investigating reasons behind reading difficulties which seem to be neglected in the previous studies can bring more insights into the reading process and help learners and teachers overcome the difficulties.

Muijselaar et al. (2017) and Mehrdad et al. (2012) investigated the interrelationship of reading strategies and reading comprehension at school and university levels respectively. Findings of the two studies revealed a significant effect of learners' awareness of reading strategies on reading comprehension. Muijselaar et al. (2017) suggested investigating high-order cognitive reading strategies that university learners should be equipped with. However, social-affective strategies, which advocate cooperative learning that contribute to sharing and constructing knowledge, based on social constructive theory (Vygotsky, 1978), are neglected in the university context (Havens \& Williams, 2019). These strategies are important for the development of cognitive and metacognitive strategies (Havens \& Williams, 2019). This has provided a scope for investigating the three types of reading strategy (metacognitive, cognitive and social-affective) thoroughly and empirically.

Learners are the vital figures in the teaching and learning process as stressed by the learnercentered approach (Doyle, 2012). They are the best informants about their reading experiences (Liu \& Brown, 2019) and, thus, investigating the acquisition process of advanced reading skills from the perspective of learners who suffer the problem may give insights into the theoretical knowledge about how advanced reading skills are acquired. The study can help learners, teachers, curricula developers and policy makers be aware of the acquisition of advanced reading skills at the tertiary level. This may enhance the learning and teaching process and contribute to the development of EFL advanced reading skills that can lead to the enhancement of learners' academic performance at the tertiary context.

Based on the practical experience of the researcher as an EFL teacher for reading courses to EFL students in a private university for a couple of years and also on review of literature on reading comprehension (e.g. Afflerbach et al., 2008; Hermida, 2009; Liu \& Brown, 2019; Muijselaar et al., 2017; Wulfemeyer, 2019), EFL learners at tertiary level encounter some difficulties in acquiring advanced reading skills (e.g. Wulfemeyer, 2019) caused by some factors that need to be investigated (Dirgantari \& Susantiningdyah, 2020). Hence, identifying reading difficulties can be the first step towards adopting reading strategies which are crucial for overcoming the reading difficulties (Martin, 2019) and enhancing learners' advanced reading skills (Kraut et al., 2016; Suraprajit, 2019; Wulfemeyer, 2019). Yet, reading strategies have not been investigated in-depth and holistically from 
EFL learners' perspective (Qrqez \& Ab Rashid, 2017) and through interviews (Chen \& Chen, 2015).

Additionally, a study that exclusively and empirically explores potential reading difficulties, reasons and reading strategies, is scarcely found. Thus, the main purpose of this study was to explore EFL tertiary learners' perceptions on the acquisition of advanced reading skills to give insights into the difficulties they encounter during reading, reasons behind difficulties, and the strategies adopted to deal with the difficulties and enhance advanced reading skills.

\section{METHOD}

The main focus of the study was to explore the advanced reading process at EFL tertiary level in a private university in Yemen. As such, I thought of engaging learners in an introspective process (Crook, 2012) in which they reflected on the reading process of the advanced reading course. The qualitative approach was adopted for collecting data (Creswell, 2014).

\section{Participants}

Participants of the study were second level female students in the department of English, in a private university, in the second semester of the academic year 2015- 2016. They were native speakers of Arabic and studied English as a foreign language for six years in public schools or 12 years in private schools before joining university. At the university, they had already studied two reading comprehension courses (I \& II) and were supposed to have gained pre-requisite reading skills for the advanced reading course. Of the 97 students who enrolled for the course in two groups $(1 \& 2)$, only 17 students $(10$ from group (1) \& 7 from group (2)) agreed to participate in a focus group discussion.

\section{Instrument}

A focus group discussion was used to gather data (Nyumba et al., 2018) from learners. The focus group discussion assisted in eliciting participants' perspectives about the acquisition process of the advanced reading skills i.e. difficulties learners encountered, reasons behind difficulties and strategies they employed to deal with difficulties and achieve the intended advanced reading purpose.

\section{Data collection procedures}

One week before the end of the semester (week 11), I got permission from the English department at the private university to conduct the study. One week later, I visited the students and requested volunteers from the two groups to participate in a focus group discussion, widely used in qualitative research (Nyumba et al., 2018), to gather in-depth and intensive data. I made it clear to the students that it would be an informal discussion about the reading process they had undergone during the study of the advanced reading course. In so doing, the plan was prepared; the purpose of the study and the thoughts to be discussed were written down; the place and time of the discussion were determined and the number of the group members was decided. The number of participants (10 or 7) was big enough for discussing and generating the participants' perspectives and small enough to manage (Rabiee, 2007). I informed the participants that the collected data would be used for research purposes and their personal information would remain confidential. I also informed them that they were allowed to speak Arabic if they were not able to express their thoughts in English. However, only very few of them ( 3 of the 17) used some Arabic phrases which were translated by the researcher into English.

I invited the participants of group one to the focus group discussion in the due time which lasted for 90 minutes. I welcomed the participants and sought their permission to tape-record the interview so that I would not miss the important details they would provide. I told them that there would be no wrong answers and they could express their views freely even if others would not agree with them. I also informed them that everyone should feel free to withdraw any time during the discussion if she does not feel relaxed. However, only one student left towards the end of the focus group discussion as it was time for her to go home.

During the focus group discussion, I acted as a moderator to organize the discussion, give everyone a chance to express her opinion, and probe participants to get thorough ideas about the issues discussed. The participants were first requested to talk about the difficulties they encountered during advanced reading course and why they thought they faced these difficulties.

During the discussion, I took notes of the main points provided by the participants, in addition to audio-taping the discussion. After saturation was reached (Mason, 2010), I summarized the difficulties and reasons behind the difficulties discussed to seek approval from participants that the difficulties and reasons they mentioned were the ones they had experienced during the course. This was done to ensure the reliability of the data (Lincoln \& Guba, 2009). Then the participants were asked about what roles they played and what the teacher did in reading classes to infer adopted reading strategies. I ended up summarizing the main points of discussion and got participants' approval for what they had said about reading strategies. The same procedures were employed with the participants of group two.

\section{Data Analysis}

The main analysis of the collected data was done after the focus group discussions were completed. The initial analysis started during the focus group discussions. Then the audiotaped data were transcribed and grammatical errors in the 
participants' utterances were corrected. The Arabic phrases used by some students were translated into English. Kvale's (1996) methods were adopted for analyzing and interpreting the interviews i.e. summarizing the meaning expressed by interviewees into brief statements, coding meaning into categories, creating coherent stories, interpreting deep meaning of the text and generating meaning through different methods such as words, and figures. The emerging themes of difficulties, reasons and strategies from the discussions of the two groups were integrated and shown in Figure (1).

\section{FINDINGS AND DISCUSSION}

Findings elicited from the analysis of focus group discussions revealed that EFL learners at the private university encountered difficulties during the reading process of the advanced reading course which were attributed to certain reasons. Findings also revealed the strategies used to deal with the reading difficulties. Figure (1) summarizes the emerging themes of the reading difficulties encountered by learners, reasons behind difficulties and the reading strategies adopted by learners.

Figure 1

Reading Difficulties, Reasons and Reading Strategies in the Advanced Reading Course

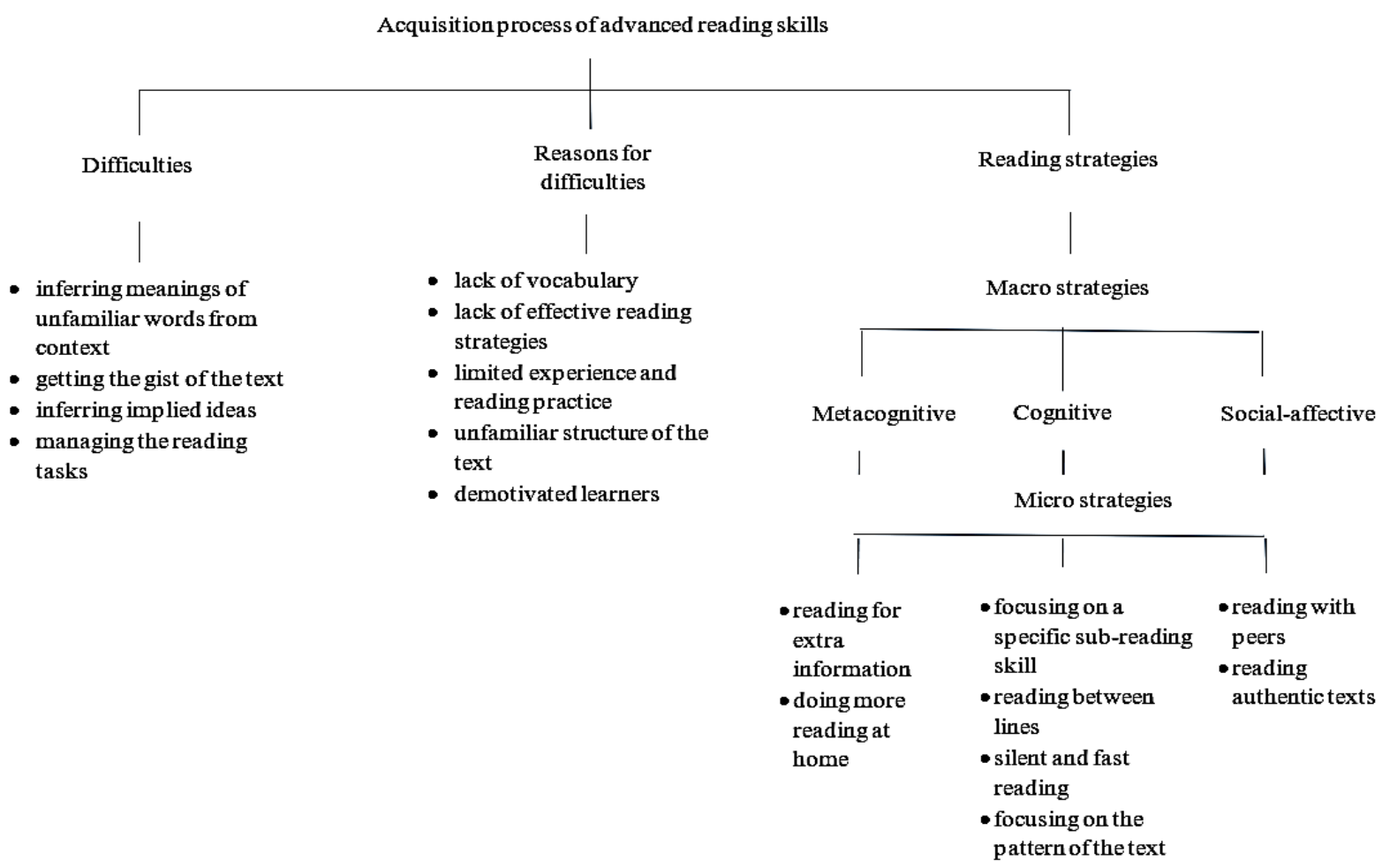

\section{Reading difficulties}

The reading difficulties that participants encountered during the study of the advanced reading course are discussed below.

\section{Inferring meanings of unfamiliar words from context}

Most of participants reported that they faced difficulty in inferring meanings of unfamiliar words from context. They narrated: "We face great difficulty in eliciting the meaning of new words in the text". This finding is similar to findings of some studies conducted on reading comprehension at EFL tertiary level such as Kasim and Raisha (2017) and Manihuruk (2020), which revealed that learners faced great difficulty in inferring meanings of words from context. Some ESL teachers view vocabulary vital for mastering reading skills (Hugo, 2014;
Zhang, 2012) and tend to teach new words in their reading classes (Kraut et al., 2016) which is not the main focus of reading comprehension particularly for advanced readers; in communicative language, the focus in reading should be on the discourse rather than on vocabulary which can be learnt through an adequate exposure to the language (Peters, 2018) as meaning can be guessed from context (Hardanti et al., 2015).

\section{Getting the gist of the reading text}

Comprehending the gist of the reading text was another difficulty encountered by learners. Some participants pointed out that they did not sometimes understand the meaning of the whole text or what the text was about. This is similar to findings of the studies conducted by Ibrahim and Ahmed (2020) on reading comprehension among Arab EFL university 
learners which indicated that learners face difficulty in linking the ideas of the text to construct general meaning. For constructing comprehensive meaning of the reading text, different skills are required to interrelate and coordinate (Qrqez \& Ab Rashid, 2017), not just at the word and sentence level, but also at the text level (Qrqez \& Ab Rashid, 2017).

\section{Inferring implied ideas}

Participants mentioned that they only understood the stated ideas in the texts, but they found inferring implied ideas problematic. This finding is similar to that of Ibrahim and Ahmed (2020) in their study on reading which concluded that inferring implied information and ideas in the reading text is a great difficulty encountered by EFL university learners. Eliciting implied ideas is the most crucial and highorder reading comprehension skill (Tarchi, 2015), which requires advanced reading strategies (Kendeou et al., 2014) that can enhance learners' reading comprehension (Kendeou et al., 2014).

\section{Managing reading tasks}

Participants also faced difficulty in managing reading tasks. They mentioned that, for a long time, they did not know how to read and what to do when they read. Some participants' narrations emphasized the important role of the teacher in making learners aware of reading strategies: "Teachers should encourage us and teach us how to read". Ibrahim and Ahmed's (2020) study revealed a similar finding. The authors indicated that EFL university learners face difficulty in managing to link the ideas in the different parts of the text. However, guiding learners to use effective reading strategies will help them manage reading and enhance their reading skills (Afflerbach et al., 2008).

\section{Reasons for reading difficulties:}

Reading difficulties that learners encountered in the advanced reading course could be attributed to the following reasons discussed below.

\section{Lack of vocabulary}

Some participants mentioned that the reasons behind reading difficulties could be learners' lack of vocabulary. This is similar to findings in Raihan and Nezami's (2012) study which refers the difficulty in constructing meaning to the lack of learners' vocabulary. Vocabulary knowledge, which can be developed through intensive and extensive reading (Guo, 2020) is important for comprehending reading texts, enhancing reading habits (Guo, 2020; Mermelstein, 2014; Nergis, 2013) and developing reading skills (Perfetti et al., 2005).

\section{Lack of effective reading strategies}

Some reading difficulties such as difficulty in understanding the meaning and general idea of the text could be attributed to the lack of effective reading strategies as narrated by participants: "Some teachers provide the meaning of unfamiliar words, but they do not teach students how to infer meaning from context". This finding has been emphasized by Kasim and Raisha's (2017) study which revealed that the lack of reading strategy knowledge among EFL learners has created reading difficulties such as eliciting main and sub ideas of the text. These inferences making difficulties are perhaps due to the learners' adoption of the surface approach to reading which only focuses on low order cognitive skills neglecting the deep approach which is concerned with high order cognitive skills (Hermida, 2009). Raising learners' awareness of how to read could help in motivating them to develop effective reading strategies.

\section{Limited experience and reading practice}

Participants attributed the difficulties they faced in reading to their limited experience and reading practice inside and outside classroom. Most of them stressed that their "reading is limited to course related materials ... and that impedes reading comprehension". They stated: "We rarely apply the reading strategies we have learnt in advanced reading". This finding is in congruence with what Qrqez and Ab Rashid (2017) found in their study that limited reading practice in the classroom prevents learners to deal with reading difficulties. Limited reading practice creates poor readers (Ismail \& Yusof, 2016); however, engaging learners in sufficient reading experience aids to develop reading skills (Clinton, 2019).

\section{Unfamiliar structure of the text}

Participants revealed that they faced reading difficulties which were perhaps due to the unfamiliar text structure. They stated that "some students do not comprehend the text because of the structure of the text"; they mentioned that "some reading texts have unclear structure; and teachers should explain the structure of the text for learners". This finding is similar to what Ibrahim and Ahmed (2020) emphasized in their study that many reading problems arise as a result of the pattern of the text. Making learners aware of the structure of texts (Namjoo \& Marzban, 2014) can help them identify the main idea in the text and develop the skill of getting the gist of the whole text (Rohman, 2017).

\section{Demotivated learners}

Participants revealed that demotivation was one of the essential reasons for the reading difficulties that learners encounter in reading. To put it in participants' words: "I think some students lack the desire to improve their reading skills"; "some teachers are very strict and some are very lenient, but a teacher should be flexible and encourage students to learn". Motivation is an important factor for reading (Trehearne \& Doctorow, 2005) as constructing meaning of the reading text may heavily rely on reader's motivation (Davoudi \& 
Yousefi, 2015). When teachers develop motivated learners, the latter can find their own way to enhance their reading skills (Mermelstein, 2014).

\section{Reading strategies adopted by learners:}

Findings revealed strategies that learners adopted to deal with reading difficulties in the advanced reading course. These strategies include (a) cognitive, (b) metacognitive and (c) social-affective. This finding is similar to findings of studies conducted by Al Seyabi and Tuzlukova (2015) and Al-Sobhani (2013) which revealed learners' use of cognitive, metacognitive and support strategies. The third type (support) is equivalent to social-affective strategies used by learners in the current study. The above macro strategies are sub-classified into some further micro strategies as follows:

\section{Cognitive strategies:}

Using cognitive reading strategies in class can help EFL learners achieve the objectives of reading comprehension and enhance their reading skills (Wahyono, 2019). Findings showed that cognitive strategies used by learners involve the following:

\section{Focusing on a specific sub-reading skill}

Participants mentioned that, in every reading class, they had the opportunity to practise a particular subreading skill. They stated: "In every class, we read different types of texts and practised one skill. For example, in one class, we learnt to elicit the main idea in every text". Focusing on a specific subreading skill in every class repeatedly using different exercises assists learners to improve reading skills effectively (Kraut et al., 2016).

\section{Reading between lines}

Reading between lines was a strategy used in reading classes. This strategy was stated by some participants: "I learnt how to elicit the topic of the text"; "I learnt how to answer questions based on deep understanding", and "We learnt some reading skills such as how to elicit main idea and sub ideas in the text". This advanced reading strategy (Tarchi, 2015), which adopts the deep reading approach (Hermida, 2009) helps readers to gain deeper understanding by going beyond the text (Suraprajit, 2019).

\section{Silent and fast reading}

Silent and fast reading was a strategy that participants practised throughout the course as they narrated: "We practised silent and fast reading in class". This strategy is perceived as important for advanced learners (Korinth \& Fiebach, 2018) who require advanced language to develop their advanced reading skills (Ari, 2017).

\section{Focusing on the pattern of the text}

The identification of the pattern of the text was one strategy that participants employed during reading.
This was evident in the participants' talk: for example, "We learnt to identify different patterns of texts". They believed that this strategy helped to follow the flow of ideas and details. Awareness of the text pattern helps to determine the central idea and details (Rohman, 2017), increase the comprehension of the reading text (Namjoo \& Marzban, 2014), and facilitate learners' comprehension, fluency and efficiency (Meyer \& Ray, 2011).

\section{Metacognitive strategies:}

Metacognitive strategies adopted in advanced reading classes include reading different resources for extra information and doing more reading at home. These strategies help readers to be aware of what they are going to read (Meniado, 2016) and also assist in monitoring cognitive strategies (Al Seyabi \& Tuzlukova, 2015) and developing fluent reading skills (Grabe, 1991).

\section{Reading for extra information}

Gathering information by reading various sources was a new experience for participants. This was clearly stated by some participants: "We learnt how to search for information from different reading sources"; and "We learnt to read and summarize texts". At this advanced level, developing metacognitive skills enable learners to synthesize and evaluate information from different sources (Grabe, 1991).

\section{Doing more reading at home}

Most of the participants believed that reading extra materials outside class helped them improve their reading skills. They stated: "The teacher used useful strategies by asking us to do more reading at home" and "The teacher gave us more assignments on reading". Giving learners the opportunity to do such extensive reading tasks can help in activating learners' prior knowledge, develop their cognitive reading strategies and skills (Afflerbach et al., 2008) and transfer such strategies to new reading tasks (Chamot \& Kupper, 1989).

\section{Social-affective strategies:}

Findings revealed that social-affective strategies were adopted during the advanced reading course. These strategies, which include reading with peers and reading authentic texts, aid learners share prior knowledge of the reading text (Tarchi, 2015) and attain the reading purpose (Liu \& Brown, 2019).

Reading with peers

Participants mentioned that they used the strategy of reading with peers in class which gave them the opportunity to "learn from each other and develop thinking skills". This finding was emphasized by Tarchi (2015). The strategy of reading with peers develops learners' critical thinking and reading comprehension skills (Tarchi, 2015), in addition to 
their metacognitive skills (Kenner \& Weinerman, 2011).

\section{Reading authentic texts}

Reading authentic texts was adopted and admired by participants who emphasized that "one of the good strategies that the teacher used is providing authentic passages for reading exercises in class". They found this strategy effective as it provided them with the opportunity to work on texts about real life issues such as fashion, technology and war which helped them visualize the context of reading. This strategy is supported by the view that working on authentic texts is a challenging and risk-taking task which can help to enhance EFL/ ESL learners' reading comprehension skills (Taghavi \& Aladini, 2018). As such, this strategy can help to prepare EFL learners for the actual life situation where they have to read and react to authentic texts (Taghavi \& Aladini, 2018).

\section{CONCLUSION}

The study aimed to explore the acquisition of advanced reading skills among EFL learners at tertiary level in Yemeni context. It has addressed the gap in literature pertaining to reading difficulties encountered by learners, reasons behind difficulties and strategies adopted to deal with the difficulties and achieve the intended advanced reading skills. In the acquisition process of advanced reading skills, learners face linguistic and non-linguistic difficulties. These difficulties can be attributed to factors related to learners, text and instruction.

Engaging learners in a reading process using a multifaceted reading strategy (metacognitive, cognitive and social-affective) enable them to deal with emerging reading difficulties and move towards acquiring the intended advanced reading skills. Besides, focusing on the three types of strategy will develop critical and autonomous readers who are well-equipped with effective reading strategies.

EFL learners should be motivated to approach reading as future life skill; and reading strategies should be introduced gradually during reading classes. This can be done by adopting a learnercentered approach in reading where the teacher plays the role of a facilitator and provides learners with the opportunity to have their own reading text preferences. This can help learners apply reading strategies they learn and examine which strategy fits what text and context. Furthermore, integrating intensive and extensive reading approaches can develop their own strategies over time, which will eventually lead to the enhancement of advanced reading skills and academic performance.

Further studies can investigate reading strategies in relation to reading fluency and which type of strategy has more impact on fluency. For collecting more reliable data on reading strategies used in class, observation can be an effective research tool.

\section{REFERENCES}

Afflerbach, P., Pearson, P. D., \& Paris, S. G. (2008). Clarifying differences between reading skills and reading strategies. The Reading Teacher, 61, 364-373. https://doi.org/10.1598/RT.61.5.1

Ahmadi, R. A., Ismail, H. N., \& Abdullah, M. K. (2013). The importance of metacognitive reading strategy awareness in reading comprehension. English Language Teaching, 6(10), 235-249. https://doi.org/10.5539/elt.v6n10p235

Al Seyabi, F., \& Tuzlukova, V. (2015). Investigating EFL reading problems and strategies in post-basic schools and university foundation programmes: A study in the Omani context. Malaysian Journal of ELT Research, 11(2), 35-51.

Allen, J. V., \& Zygouris-Coe, V. (2019). Using guided reading to teach internet inquiry skills: A case study of one elementary school teacher's experience. Reading Psychology, 40(5), 425-464. https://doi.org/10.1080/02702711.2019.16239 61

Al-Sobhani, Y. A. (2013). Metacognitive reading strategies use by Yemeni EFL undergraduate university students. Frontiers of Language and Teaching, 4, 121-130.

Ari, G. (2017). Basic concepts of reading instruction. International Journal of Languages' Education and Teaching, 5(4), 484-503. https://doi.org/10.18298/ijlet.2390

Chamot, A. U., \& Kupper, L. (1989). Learning strategies in language learning instruction. Foreign Language Annals, 22, 13-34.

Chen, S. C., \& Chen, K. T. (2015). The use of EFL reading strategies among high school students in Taiwan. The Reading Matrix, 15(2), 156166.

Clinton, V. (2019). Reading from paper compared to screens: A systematic review and metaanalysis. Journal of Research in Reading, 42(2), 1-38. https://doi.org/10.1111/14679817.12269

Creswell, J. W. (2014). Research design: Qualitative, quantitative and mixed methods approaches (4th ed.). Sage.

Crook, D. (2012). Teacher education as a field of historical research: Retrospect and prospect. History of Education, 41(1), 57-72. https://doi.org/10.1080/0046760X.2012.6495 78

Davoudi, M., \& Yousefi, D. (2015). Comprehension breakdown: A review of research on EFL learners' reading difficulty and problems. International Journal of Language and Applied Linguistics, 1, 58-72. 
Dirgantari, A. S., \& Susantiningdyah, H. (2020). Students' reading comprehension skill: The roles of text readability and question difficulty. PEOPLE: International Journal of Social Sciences, 6(1), 533-544. https://doi.org/10.20319/pijss.2020.61.533544

Doyle, T. (2012). Learner-centered teaching: Putting the research on learning into practice. Stylus Publishing.

Elihami. (2017). Increasing students' reading comprehension through cognitive strategies of Senior High School of Sidenreng Rappang Regency. Lingua Cultura, 11(2), 103-107. https://doi.org/10.21512/lc.v11i2.921

Fitriani, S. S. (2014). An investigation into reading comprehension strategies in academic texts in Aceh Province of Indonesia. The Third International Conference on Language Education 2013 (ICOLE 3), 95-126.

Goodman, K. (1970). Reading: A psycholinguistic guessing game. In H. D. Brown (Ed.), Teaching by principles: An interactive approach to language pedagogy $\left(3^{\text {rd }} \mathrm{ed}\right.$.) ( $\mathrm{pp}$. 357-389). Pearson Longman.

Grabe, W. (1991). Current developments in second language reading research. TESOL Quarterly, 25(3), 375-406. https://doi.org/10.2307/3586977

Guo, Y. (2020, March). Application of sustained silent reading in different stages of English learning. International Conference on Modern Educational Technology and Innovation and Entrepreneurship (ICMETIE 2020) (pp. 275-278). Atlantis Press.

Hardanti, E., Sutarsyah, C., \& Yufrizal, H. (2015). The implementation of guessing meaning from context in improving students' reading skill [Unpublished doctoral dissertation]. Lampung University.

Havens, P. S., \& Williams, M. S. (2019). University peer-assisted learning strategies in the humanities. Journal of College Reading and Learning, 49(3), 160-169. https://doi.org/10.1080/10790195.2019.16353 71

Hermida, D. (2009). The importance of teaching academic reading skills in first-year university courses. The International Journal of Research and Review, 3, 20-30. https://doi.org/10.2139/ssrn.1419247

Hugo, A. J. (2014). Acquiring reading skills in English as second language: Listening to the voice of grade 1 teachers in South Africa. International Journal of Educational Sciences, 6(2), 317-323. https://doi.org/10.1080/09751122.2014.11890 143

Ibrahim, T. M. A. E., \& Ahmed, M. A. (2020). Investigating teacher's views and perceptions about how to improve reading comprehension skills. Journal of Linguistic and Literary Studies, 21(2), 72-81.

Ismail, A., \& Yusof, N. (2016). Readability of ESL picture books in Malaysia. Journal of Nusantara Studies, 1(1), 60-70. https://doi.org/10.24200/jonus.vol1iss1pp6070

Iwai, Y. (2011). The effects of metacognitive reading strategies: Pedagogical implications for EFL/ESL teachers. The Reading Matrix, 11(2), 150-157.

Kasim, U., \& Raisha, S. (2017). EFL students' reading comprehension problems: Linguistic and non-linguistic complexities. English Education Journal, 8(3), 308-321.

Kendeou, P., Van Den Broek, P., Helder, A., \& Karlsson, J. (2014). A cognitive view of reading comprehension: Implications for reading difficulties. Learning Disabilities Research and Practice, 29(1), 10-16. https://doi.org/10.1111/ldrp.12025

Kenner, C., \& Weinerman, J. (2011). Adult learning theory: Applications to nontraditional college students. Journal of College Reading and Learning, 41(2), 87-96. https://doi.org/10.1080/10790195.2011.10850 344

Korinth, S. P., \& Fiebach, C. J. (2018). Improving silent reading performance through feedback on eye movements: A feasibility study. Scientific Studies of Reading, 22(4), 289-307. https://doi.org/10.1080/10888438.2018.14390 36

Kraut, R., Chandler, T., \& Hertenstein, K. (2016). The interplay of teacher training, access to resources, years of experience and professional development in tertiary ESL reading teachers' perceived selfEfficacy. Gist: Education and Learning Research Journal, (12), 132-151.

Kvale, S. (1996). Interviews: An introduction to qualitative research interviewing. SAGE.

Lincoln, Y. S., \& Guba, E. G. (2009). The only generalization is: There is no generalization. In R. Gomm, M. Hammersley, \& P. Foster (Eds.), Case Study Method (pp. 27-45). Sage.

Liu, X., \& Brown, G. T. (2019). Investigating students' perceived cognitive needs in university academic reading: A latent variable approach. Journal of Research in Reading, 42(2), 411-431. https://doi.org/10.1111/1467-9817.12275

Lyon, G. R., Shaywitz, S. E., \& Shaywitz, B. A. (2003). Defining dyslexia, comorbidity, teacher's knowledge of language and reading. Annals of Dyslexia, 53(1), 1-14. https://doi.org/10.1007/s11881-003-0001-9

Manihuruk, D. H. (2020). The correlation between EFL students' vocabulary knowledge and reading comprehension. JET- Journal of 
English Teaching, 6(1), 86-95.

https://doi.org/10.33541/jet.v6i1.1264

Martin, N. M. (2019). Processing different kinds of expository text: An investigation of students' strategy use in post-secondary education. Journal of College Reading and Learning, 49(1), 3-18.

https://doi.org/10.1080/10790195.2018.14729 44

Mason, M. (2010). Sample size and saturation in $\mathrm{PhD}$ studies using qualitative interviews. Forum: qualitative social research, 3(11). https://doi.org/10.17169/fqs-11.3.1428

Mehrdad, A. G., Ahghar, M. R., \& Ahghar, M. (2012). The effect of teaching cognitive and metacognitive strategies on EFL students' reading comprehension across proficiency levels. Procedia-Social and Behavioral Sciences, 46, 3757-3763. https://doi.org/10.1016/j.sbspro.2012.06.142

Meniado, J. C. (2016). Metacognitive reading strategies, motivation, and reading comprehension performance of Saudi EFL students. English Language Teaching, 9(3), 117-129. https://doi.org/10.5539/elt.v9n3p117

Mermelstein, A. D. (2014). Improving EFL learners' reading levels through extensive reading. Reading Matrix: An International Online Journal, 14(2), 227-242.

Meyer, B. J., \& Ray, M. N. (2011). Structure strategy interventions: Increasing reading comprehension of expository text. International Electronic Journal of Elementary Education, 4(1), 127-152.

Muijselaar, M. M., Swart, N. M., SteenbeekPlanting, E. G., Droop, M., Verhoeven, L., \& de Jong, P. F. (2017). Developmental relations between reading comprehension and reading strategies. Scientific Studies of Reading, 21(3), 194-209. https://doi.org/10.1080/10888438.2017.12787 63.

Namjoo, A., \& Marzban, A. (2014). A new look at comprehension in EFL/ESL reading classes. Procedia-Social and Behavioral Sciences, 116, 3749-3753. https://doi.org/10.1016/j.sbspro.2014.01.835

Nergis, A. (2013). Exploring the factors that affect reading comprehension of EAP learners. Journal of English for Academic Purposes, 12, 1-9. https://doi.org/10.1016/j.jeap.2012.09.001

Nyumba, T. O, Wilson, K., Derrick, C. J., \& Mukherjee, N. (2018). The use of focus group discussion methodology: Insights from two decades of application in conservation. Methods in Ecology and Evolution, 9(1), 20-32. https://doi.org/10.1111/2041-210X.12860
Perfetti, C., Landi, N., \& Oakhill, J. (2005). The acquisition of reading comprehension skill. In M. J. Snowling \& C. Hulme (Eds.), The science of reading: A handbook (pp. 227247). Blackwell Publishers.

Peters, E. (2018). The effect of out-of-class exposure to English language media on learners' vocabulary knowledge. ITLInternational Journal of Applied Linguistics, 169(1), 142-168. https://doi.org/10.1075/itl.00010.pet

Poole, A. (2010). The reading strategies used by male and female English language learners: A study of Colombian high school students. New England Reading Association Journal, 46(1), 55-63.

Qrqez, M., \& Ab Rashid. R. (2017). Reading comprehension difficulties among EFL learners: The case of first and second -year students at Yarmouk University in Jordan. Arab World English Journal, 8(3). https://doi.org/10.24093/awej/vol8no3.27

Rabiee, F. (2007). Focus-group interview and data analysis. Proceedings of the Nutrition Society, 63(4), 655-660. https://doi.org/10.1079/PNS2004399

Raihan, S., \& Nezami, A. (2012). A critical study of comprehension strategies and general problems in reading skill faced by Arab EFL learners with special reference to Najran University in Saudi Arabia. International Journal of Social Sciences and Education, 2(3), 306-316.

Rasinski, T (2019). Introduction to special issue of reading psychology on reading fluency. Reading Psychology, 40(4), 325-328. https://doi.org/10.1080/02702711.2018.15553 60

Rohman, A. (2017). Improving students' reading comprehension through text structure tasks. Script Journal: Journal of Linguistic and English Teaching, 2(1), 1-12. https://doi.org/10.24903/sj.v2i1.74

Sahrul, S. (2014). Applying cognitive reading strategy to develop students reading comprehension. UNM.

Samad, I. A., Jannah, M., \& Fitriani, S. S. (2017). EFL students' strategies dealing with common difficulties in TOEFL reading comprehension section. International Journal of Language Education, 1(1), 29-36. https://doi.org/10.26858/ijole.v1i1.2869

Sheorey, R., \& Mokhtari, K. (2001). Differences in the global awareness of reading strategies among native and non-native readers. System, 29, 431-449. https://doi.org/10.1016/S0346251X(01)00039-2

Suraprajit, P. (2019). Bottom-up vs top-down model: The perception of reading strategies among Thai university students. Journal of 
Language Teaching and Research, 10(3), 454-460. https://doi.org/10.17507/jltr.1003.07

Taghavi, F., \& Aladini, F. (2018). The effect of modified vs. authentic input on Iranian EFL learners' reading comprehension. Theory and Practice in Language Studies, 8(4), 450-457. http://dx.doi.org/10.17507/tpls.0804.13

Tarchi, C. (2015). Fostering reading comprehension of expository texts through the activation of readers' prior knowledge and inference-making skills. International Journal of Educational Research, 72, 80-88. https://doi.org/10.1016/j.ijer.2015.04.013

Trehearne, M. P., \& Doctorow, R. (2005). Comprehensive literacy resource: Grade 3-6. ETA Cuisenaire.

Veeravagu, J. V. J., Muthusamy, C., Marimuthu, R., \& Michael, A. S. (2010). Using Bloom's taxonomy to gauge students' reading comprehension performance. Canadian Social Science, 6(3), 205-212. https://doi.org/10.3968/j.css.19236697201006 03.023

Vygotsky, L. S. (1978). Mind in society. Harvard University Press.

Wahyono, E. (2019). Correlation between students' cognitive reading strategies and reading comprehension. Jurnal Studi Guru dan Pembelajaran, 2(3), 256-263. https://doi.org/10.30605/jsgp.2.3.2019.61
Warrican, S. J., Alleyne, M. L., Smith, P., Cheema, J., \& King, J. R. (2019). Peer effects in the individual and group literacy achievement of high-school students in a bi-dialectal context. Reading Psychology, 40(2), 117-148. https://doi.org/10.1080/02702711.2019.15715 45

Wulfemeyer, J. (2019). Modeling metacognition and providing background knowledge via guided reading videos. Journal of College Reading and Learning, 1-14. https://doi.org/10.1080/10790195.2018.15142 84

Yukselir, C. (2014). An investigation into the reading strategy use of EFL prep-class students. Social and Behavioral Sciences Journal, 158, 65-72. https://doi.org/10.1016/j.sbspro.2014.12.034

Zhang, D. (2012). Vocabulary and grammar knowledge in second language reading comprehension: A structural equation modeling study. The Modern Language Journal, 96(4), 558-575. https://doi.org/10.1111/j.15404781.2012.01398.x

Zhussupova, R., \& Kazbekova, M. (2016). Metacognitive strategies as points in teaching reading comprehension. Procedia-social and Behavioral Sciences, 228, 593-600. https://doi.org/10.1016/j.sbspro.2016.07.091 